\title{
Relationship between blood Lead status and anemia in Ugandan children with malaria infection
}

\author{
Ambrose Mukisa, Denis Kasozi, Claire Aguttu, Peter C. Vuzi and Joseph Kyambadde* (D)
}

\begin{abstract}
Background: In Uganda, childhood anemia remains a health challenge and is associated with malaria infection as well as iron deficiency. Iron deficiency is intertwined with nutritional status, age and other comorbidities including helminths and Lead toxicity. Environmental Lead levels accounts for one's blood Lead (BL) levels. Blood Lead competitively blocks iron absorption, inhibits hemoglobin $(\mathrm{Hb})$ biosynthesis and elevates free erythrocyte protoporphyrin (FEP) levels. Lead toxicity's contribution towards anemia pathogenesis, especially during malaria infection has not been studied. Concomitant exposure to both malaria infection and Lead pollution, exacerbates the anemia status. This study therefore aimed at expounding the anemia status of these Ugandan children aged under 5 years who are exposed to both malaria infection and environmental Lead pollution.
\end{abstract}

Methods: Briefly, venous blood samples from 198 children were microscopically assayed for malaria parasite density $(\mathrm{PD})$, and hemoglobin $(\mathrm{Hb})$ concentrations using the cyanmethemoglobin method, while BL and FEP levels were determined by the standard atomic absorption spectrophotometric and fluorometric methods respectively.

Results: One hundred and fifty-one (76.3\%) of the children analyzed had moderate anemia ( $\mathrm{Hb}<10>5 \mathrm{~g} / \mathrm{dL}$ ) with Means of $B L L=8.6 \mu \mathrm{g} / \mathrm{dL}, \mathrm{Hb}=7.5 \mathrm{~g} / \mathrm{dL}, \mathrm{FEP} / \mathrm{Hb}=8.3 \mu \mathrm{g} / \mathrm{g}$ and $\mathrm{PD}=3.21 \times 10^{3}$ parasites $/ \mu \mathrm{L}$, while eight (4\%) were severely anemic ( $<5 \mathrm{~g} / \mathrm{dL})$. Regression analysis and statistical correlation between PD and $\mathrm{Hb}\left(r=-0.231, R^{2}=0.15 P\right.$-value $\left.<0.001\right)$ was negative and weak as compared to that between FEP/Hb and $\mathrm{Hb}\left(r=-0.6, \mathrm{R}^{2}=0.572 \mathrm{P}\right.$-value $\left.=0.001\right)$.

Conclusion : Based on the study's findings, we conclude that BL significantly contributes to the pathogenesis of anemia and therefore its co-existence with malaria infection in the host exacerbates the anemia status.

Keywords: Blood Lead, Malaria parasites, Anemia, Iron deficiency, Free erythrocyte protoporphyrins

\section{Background}

Like many malaria holoendemic developing countries, Uganda is faced with health-threatening diseases including anemia. Majority (60\%) of the Uganda's urban poor live in social disadvantaged slums like Katanga, Kampala $[1,2]$. In such areas people live next to industries, workshops, motor garages, metal crafts yards, battery recycling plants, mosquito breeding grounds, and landfills

\footnotetext{
* Correspondence: joseph.kyambadde@gmal.com

Department of Biochemistry and Sports Science, College of Natural Sciences, Makerere University, Kampala, Uganda
}

predisposing them to frequent malaria infections as well as Lead intoxication. Several studies report elevated environmental Lead levels in water sources, soils, foodstuffs and air around Kampala city [3].

Malaria and Lead pollution geographically overlap, with water acting as sinks to Lead contaminated runoffs as well as bleeding ground for mosquitos. According to a study by [4], malaria infection accounts for up to $40 \%$ of all hospital outpatient visits, $25 \%$ of all hospital admissions, and $14 \%$ of all hospital deaths $[4,5]$ despite government efforts to curb its transmission [6]. Already

(c) The Author(s). 2020 Open Access This article is licensed under a Creative Commons Attribution 4.0 International License, which permits use, sharing, adaptation, distribution and reproduction in any medium or format, as long as you give appropriate credit to the original author(s) and the source, provide a link to the Creative Commons licence, and indicate if changes were made. The images or other third party material in this article are included in the article's Creative Commons licence, unless indicated otherwise in a credit line to the material. If material is not included in the article's Creative Commons licence and your intended use is not permitted by statutory regulation or exceeds the permitted use, you will need to obtain permission directly from the copyright holder. To view a copy of this licence, visit http://creativecommons.org/licenses/by/4.0/ The Creative Commons Public Domain Dedication waiver (http://creativecommons.org/publicdomain/zero/1.0/) applies to the data made available in this article, unless otherwise stated in a credit line to the data. 
fifty-three percent of children under the age of 5 years in Katanga area are reported to be anemic [6-9] this being attributed to high malaria prevalence.

Although, malaria infections remain the key cause of anemia in Uganda, other neglected yet significant confounders contributing to its pathogenesis include Lead poisoning, nutritional status, and helminths among others [6-9]. Lead exposure accounts for an individual's blood Lead level (BLL) and is more evident in developing fetus where it directly affects the hematopoietic system. Ninety-nine percent of all the BL sink in the erythrocytes and $80 \%$ of it bind the $\delta$-aminolevulinic acid dehydratase ( $\delta$-ALAD) enzyme. This enzyme is believed to catalyze the formation of porphobilinogen from $\delta$-aminolevulinic acid (ALA) [10]. During Lead intoxication, BL inhibits activity(s) of ALAD and limit the transfer of iron from endosomes to the cytoplasm resulting into fragile cell membrane which in turn shorten the lifespan of the circulating erythrocytes [11-13].

Blood Lead further triggers a reduction in red blood cells (RBC) production by specifically inhibiting Ferrochelatase a mitochondrial enzyme that catalyzes the insertion of iron into protoporphyrin during heme formation. Aminolevulinic acid synthetase (ALAS) a mitochondrial enzyme that catalyzes the formation of aminolevulinic acid (ALA) from succinyl CoA and glycine is also affected by BL [13-16]. In a normal heme synthesis system, the rate of iron formation and utilization is well balanced, however, this equilibrium is disturbed with insufficiency of iron.

High malaria burden, overproduction of protoporphyrin, iron deficiency, inhibited ALAD and impaired ferro chelatase activity accounts for anemia pathogenesis. During malaria infection, intrinsic and extrinsic challenges are elevated and they induce iron deficiency anemia whose persistence elevates the rate at which Lead is absorbed [17-19]. In addition to other symptoms, malaria infection becomes fatal with severe anemia. Coupled with severe anemia, malaria is a result of massive erythrocytes lysis because of raising parasite density which in turn causes rupture of parasitized and non-parasitized red cells. Its persistence activates the splenic and other macrophages activities for phagocytosis [20] resulting into severe anemia.

Reduced cellular iron concentrations on the other hand enhances Lead's effects on major synthesis reactions. For example, ferrochelatase enzyme which is specifically sensitive to low iron levels is affected by lead toxicity [21]. Also zinc instead of iron is incorporated into protoporphyrin (PPN) resulting in elevated levels of zinc protoporphyrin (ZPP) [22]. Zinc protoporphyrin or FEP concentrations are key biomarkers of heme synthesis status, and therefore, their elevation in concentration is associated with iron deficiency due to heme synthesis disorders $[23,24]$.
Since red cells are at the centre of anemia pathogenesis, as well as home to both the malaria parasites and $\mathrm{BL}$, their co-existence propagates the host cell's survival challenges. The severity of anemia is dependent on the host's age and nutrition status [25, 26]. In addition, the combined aftermath of malaria parasites and $\mathrm{BL}$ among individuals living in malaria-endemic regions heighten the progression to severe anemia. This study therefore aimed at expounding the anemia status of these Ugandan children who are exposed to both malaria infection and environmental lead pollution. In this study, hemoglobin $(\mathrm{Hb})$ concentration was used as a measure of one's anemia status, and $\mathrm{FEP} / \mathrm{Hb}$ ratio for heme synthesis status.

\section{Methods}

This was a cross-sectional study on children aged 6 -60 months living in Katanga area- Kampala city. The children were first screened for Plasmodium parasite infection before recruitment using rapid diagnostic kits. Children with malaria negative test, HIV positive test, blood transfusion history and signs of malnutrition were excluded from the study. Five (5) mls of venous blood from 198 malaria positive children were collected into EDTA by Qualified Nurses and Technicians. The samples were then transported on ice to Makerere University, Biochemistry Department Laboratory, stratified according to malaria parasite density and kept at $4^{\circ} \mathrm{C}$ awaiting various analyses and determinations.

Determination of parasite density by thick smear method Thick smears were prepared as described by [27], air dried, stained with $10 \%$ Leishman without fixing and examined under a CX 21 Olympus microscope. Five hundred leukocytes plus the number of malaria parasites seen in the same field were recorded. The number of malaria parasites per microliter (parasite/ $\mu \mathrm{L}$ ) of blood was expressed as the reciprocal of the mean counts in the three slides divided by the leukocyte counts, multiplied by a factor of 8000 i.e.

Parasites $/ \mu \mathrm{L}$ blood $=\frac{\text { Number of parasites counted } \times 8000 \text { white blood cells } / \mu \mathrm{L}}{\text { No.of white blood cells counted }}$

\section{Determination of blood Lead levels by atomic absorption spectrometry}

Blood Lead levels were determined following a method described by [28] using an atomic absorption spectrophotometer (Agilent 2000 series) equipped with a graphite tube atomizer and deuterium background correction facility. A hollow-cathode Lead lamp with a working current of $5 \mathrm{~mA}, 283.3 \mathrm{~nm}$ spectral line and $0.5 \mathrm{~nm}$ bandwidth was used. Aliquots $(500 \mu \mathrm{l})$ of whole blood melted with $1.2 \mathrm{ml}$ of $0.5 \%$ Triton X-100 and $1 \%$ 
$\left(\mathrm{NH}_{4}\right)_{2} \mathrm{HPO}_{4}$ solution were added to $1.8 \mathrm{ml}$ of deionized water and $1.5 \mathrm{ml}$ of $20 \%$ Trichloroacetic acid (TCA) and vortex mixed. The samples were centrifuged for $20 \mathrm{~min}$ at $5000 \mathrm{rpm}$ and $10 \mu \mathrm{l}$ of the supernatant injected onto the graphite tube. The calibration curve was drawn using a standard addition method as described in M-572 of INSPQ's Toxicology Laboratory method.

\section{Fluorospectrophotometric quantification of free erythrocyte protoporphyrins}

The FEP was measured following a method described by [29] using a fluorospectrophotometer set at $405 \mathrm{~nm}$ excitation $610 \mathrm{~nm}$ emissions. The porphyrins were extracted by adding $20 \mu \mathrm{l}$ aliquots of whole blood to a solution containing $100 \mu \mathrm{L}$ of $10 \%$ ammonium sulfate and $5 \%$ celite and vortex mixed for $10 \mathrm{sec} .400 \mu \mathrm{l}$ of $95 \%$ ethanol was then added and vortex mixed for more 20 seconds. This was followed by addition of $600 \mu$ of acetone and further vortex mixing for 20 seconds. All the samples were put on an ice bath for $20 \mathrm{~min}$, vortex mixed for $20 \mathrm{sec}$. and centrifuged at $4{ }^{\circ} \mathrm{C}$ for $10 \mathrm{~min}$. After which the supernatants were harvested into small borosilicate tubes and aliquots of $300 \mu \mathrm{l}$ mixed with $300 \mu \mathrm{l}$ of a solution containing propylene glycol and $1.5 \mathrm{~N} \mathrm{HCI},(4: 1)$, let to stand for 20 min before reading at $405 \mathrm{~nm}$ excitation and 610 emissions. The FEP blood concentration was calculated using the following formulae;

$$
\begin{aligned}
\operatorname{FEP}(\mu \mathrm{g} / \mathrm{dL} \text { Blood }) & =\mathrm{FEP} \mu \mathrm{g} / 100 \mathrm{ml} \text { extract } \\
& =\frac{\mathrm{F}_{\mathrm{z}} \times \mathrm{C}_{\mathrm{s}} \times 2.7 \times 100}{\mathrm{~F}_{\mathrm{s}} \times 1.1 \times 0.2}
\end{aligned}
$$

Where Fz is the sample fluorescence, Cs concentration of the standard, Fs is the fluorescence of the standard, 2.7 is the final volume of $\mathrm{HCl}$ phase, 100 is the conversion factor to $100 \mathrm{ml}$ of extract, 1.1 conversion factor for protoporphyrin measured against a coproporphyrin standard and $0.2(20 \mu \mathrm{l})$ is the original blood volume measured. The $\mathrm{FEP} / \mathrm{Hb}$ ratio expressed as microgram $\mathrm{Hb}$ per gram $\mathrm{Hb}$ was calculated by dividing the FEP/dL $\mathrm{RBC}$ by gram $\mathrm{Hb} / \mathrm{dL}$.

\section{Colorimetric determination of hemoglobin levels by blood cyanmethemoglobin reaction}

Hemoglobin levels were determined by cyanmethemoglobin reaction method [30]. Aliquots $100 \mu \mathrm{l}$ of samples were made to a total volume of $1000 \mu \mathrm{l}$ with reaction solution containing $200 \mathrm{mg}$ of hexacyanoferrate III, $50 \mathrm{mg}$ of potassium cyanide, $140 \mathrm{mg}$ of potassium hydrogen phosphate and $1 \mathrm{ml}$ of Triton X-100 in a liter of distilled water. Then incubated for $15 \mathrm{~min}$ at room temperature before reading at $540 \mathrm{~nm}$, with the blank being the reaction reagent. Then $500 \mu \mathrm{l}$ of standard hemoglobin standard $(0.7 \mathrm{mg} / \mathrm{ml})$ was diluted with $500 \mu \mathrm{l}$ of the same reagent, treated as above and readings taken. The $\mathrm{Hb}$ concentration in $\mathrm{g} / \mathrm{dl}$ was calculated using formula;

$$
\text { Hb concentration }(\mathrm{g} / \mathrm{dL})=\frac{\text { OD sample } \times \text { concentration of the standard }(\mathrm{mg} / \mathrm{dL})}{\text { OD standard sample }}
$$

Where OD = optical density or absorbance at $540 \mathrm{~nm}$.

\section{Results}

Of the 198 children enrolled in the study, 8/198 (4\%) were severely anemic with $<5 \mathrm{~g} / \mathrm{dL}$, mean parasite density $=7.4 \times 10^{3}$ parasites $/ \mu \mathrm{L}$, mean $\mathrm{BLL}=9.2 \pm 4.3 \mu \mathrm{g} / \mathrm{dL}$, an $\mathrm{FEP} / \mathrm{Hb}=7.4 \pm 2.9 \mu \mathrm{g} / \mathrm{g}$. Thirty nine $(19.7 \%)$ of the study population were not anemic with a mean value of $\mathrm{Hb}>10 \mathrm{~g} \mathrm{Hb} / \mathrm{dL}$ (WHO cut off reference), mean parasite density $=1.7 \times 10^{3}$ parasites $/ \mu \mathrm{L}$, mean $\mathrm{BLL}<2 \mu \mathrm{g} /$ $\mathrm{dL}$, Mean $\mathrm{FEP} / \mathrm{Hb}=7.4 \pm 2.9 \mu \mathrm{g} / \mathrm{g}$. The details of the distribution are shown in Table 1 below

\section{Discussion}

Several cellular biomarkers are used to measure the extent and effects of blood Lead (BL) on various biochemical systems. This study explored the levels of Free erythrocyte porphyrins (FEP) as a biomarker of heme biosynthesis disorder among the study participants. The heme biosynthesis process is inactivated by either iron deficiency, failed iron regulatory system or inhibited $\delta$ aminolevulinic acid dehydratase ( $\delta$-ALAD) enzyme [31].

Free erythrocyte porphyrin levels of ${ }^{\prime} 50 \mu \mathrm{g} / \mathrm{dL}$ are important indicator of heme biosynthesis disorder. Common causes of this disorder include iron deficiency due to malnutrition and poor iron absorption, elevated hepcidin levels, and ALAD inhibition by blood Lead [16-18, $20,22,29]$. Findings of this study (Table 1 ) indicate that $88.2 \%(\mathrm{n}=175)$ of all study participants were moderately anemic $\mathrm{Hb}>5 \mathrm{~g} / \mathrm{dL}<10 \mathrm{~g} / \mathrm{dL}$. Of the 175 participants, 111 (56.6\%) had normal functioning biosynthesis system (FEP levels ' $50 \mu \mathrm{g} / \mathrm{dL}$ ), although with moderate anemia. Therefore, the observed low levels of $\mathrm{Hb}$, cannot be associated with iron deficiency. The candid cofounding factors for the observed low Hb levels therefore are oxidative stress and accumulated erythrocytic pyrimidine nucleotides. Oxidative may be caused by both BL and parasite density while the accumulated erythrocytic pyrimidine nucleotides are caused by inhibition of pyrimidine 5 nucleotidase enzyme (P5N) by BL. Enhanced oxidative challenges brought about by both parasites and Lead ions induces eryptosis, while the accumulated nucleotides cause cellular hemolysis. The study on oxidative challenges and pyrimidine nucleotide levels during both malaria infection and Lead toxicity was outside the scope of this work.

Considering the group of 39 participants (Table 1) with parasite density (PD) $\left(1.2-2.2 \times 10^{3}\right.$ parasites $/ \mu \mathrm{L}$ of 
Table 1 Distribution of parasite density, BLL, FEP/Hb and hemoglobin levels among 198 study participants

\begin{tabular}{lllll}
\hline No. of samples, $\mathbf{N}$ & $\begin{array}{l}\text { Parasite density/ } \boldsymbol{\mu L} \\
\left(\times \mathbf{1 0}^{\mathbf{3}}\right)\end{array}$ & Mean BLL $(\boldsymbol{\mu g} / \mathbf{d L})$ & $\begin{array}{l}\text { Mean FEP/Hb } \\
(\boldsymbol{\mu g} / \mathbf{g})\end{array}$ & $\begin{array}{l}\mathbf{M e a n} \mathbf{H b} \\
(\mathbf{g} / \mathbf{d L})\end{array}$ \\
\hline 16 & $0.1-1.1$ & $10.3 \pm 1.9$ & $7.9 \pm 3$ & $7.0 \pm 3.2$ \\
39 & $1.2-2.2$ & $<2$ & 0.6 & $10.4 \pm 2.7$ \\
42 & $2.3-3.3$ & $10.3 \pm 1.7$ & $2.9 \pm 3.2$ & $8.5 \pm 3.1$ \\
35 & $3.4-4.4$ & $7.9 \pm 2.1$ & $3.9 \pm 2.8$ & $9.2 \pm 3.0$ \\
34 & $4.5-5.5$ & $7.9 \pm 1.8$ & $8.4 \pm 3.2$ & $9.3 \pm 4.1$ \\
23 & $5.6-6.6$ & $6.4 \pm 1.8$ & $4.9 \pm 2.7$ & $6.8 \pm 3.3$ \\
8 & $6.7-7.7$ & $9.7 \pm 5.2$ & $7.4 \pm 2.0$ & $4.9 \pm 2.9$ \\
1 & $7.8-8.8$ & 5.1 & 5.5 & 6.7 \\
$N=198$ & Mean $=1.7 \times 10^{3}$ & Mean=8.6 & Mean=4.4 \\
\hline
\end{tabular}

Hb Hemoglobin, BLL Blood Lead levels, FEP Free erythrocyte protoporphyrin

blood), and no detectable BLL, there was a perfectly functioning heme biosynthesis system (FEP $<10 \mu \mathrm{g} / \mathrm{dL}$ ), with no anemia (mean $\mathrm{Hb}=10.4 \mathrm{~g} / \mathrm{dL}$ ). It is likely that low PD by its own may not induce anemia especially to people living in malaria endemic areas. However, coexistence with another confounding factor like BL heightens the anemia pathogenesis. We can therefore hypothesize that progression to a severe anemia status is multifactorial and is exacerbated by having both malaria infection and blood Lead simultaneously.

Table 1, further shows a $4 \%(\mathrm{n}=8)$ severe anemic group of participants $(\mathrm{Hb}<5 \mathrm{~g} / \mathrm{dL})$, with a fairly functioning heme synthesis system $(\mathrm{FEP}=36.2 \mu \mathrm{g} / \mathrm{dL}$ ) still under $50 \mu \mathrm{g} / \mathrm{dL}$ but with elevated PD. This gives an indication that the rate at which red blood cells (RBCs) were being destroyed by parasites surpassed their rate of synthesis hence the observed severe anemia status. Indiscriminate destruction of RBCs cause imbalances in the mediators of inflammation, Interleukin 6 cytokines (IL6) levels and this may affect the hepcidin expression [32, 33]. Interferon (IFN)- $\gamma$ ) known to induce the production of TRAIL (TNF-related apoptosis-inducing ligand) is also activated by elevated PD [34]. Again, the reported BLL $(9.7 \mu \mathrm{g} / \mathrm{dL})$ of this group was high enough to induce oxidative stress. As well as inhibition of P5N enzyme hence eryptosis and hemolysis respectively, likely associated with the observed low $\mathrm{Hb}$ status. It is further observed (Table 1) that 16/198 participants that had low $\mathrm{PD}$ and elevated BLL were anemic $(\mathrm{Hb}=7.0 \mathrm{~g} / \mathrm{dL})$ and suffered from iron deficiency anemia as indicated by the heme biosynthesis disorder (FEP >50 $\mu \mathrm{g} / \mathrm{dL}$ ). The group's low mean $\mathrm{Hb}$ levels could be attributed to elevated $\mathrm{PD}, \mathrm{BLL}$ and other cofounding factors like iron deficiency due to malnutrition, inhibited iron absorption and inhibited ( $\delta$-ALAD) enzyme activity.

This study reports a lower mean BLL $(=8.6 \mu \mathrm{g} / \mathrm{dL})$ compared to literature [35-37]. Furthermore, an uneven distribution of BLL among the study participants was observed. This is attributed to the fact that $\mathrm{BL}$ binds the
RBC's enzyme $\delta$-ALAD which is polymorphic with two major alleles; $\delta$-ALAD-1 and $\delta$-ALAD-2 that differ in electronegativity [38]. Having high frequency of $\delta$ ALAD-1 translates into higher $\mathrm{BL}$ burden than those with $\delta$-ALAD-2 [39].

A moderate interaction between the three variables (FEP/Hb, Parasite density and hemoglobin levels) after a multivariate analysis (Table 2) is reported. In addition, parasite density and BLL significantly correlated $(\mathrm{r}=$ 0.377, $\mathrm{P}={ }^{<} 0.001$ ) to affect the anemia status of the host Table 2. Regression analysis (Pearson's) models show that FEP: $\mathrm{Hb} \mu \mathrm{g} / \mathrm{g}$ ratio increases exponentially with the blood $\mathrm{Pb}$ while $\mathrm{Hb}$ decreased with increasing FEP (Fig. 1). Again, a negative and strong Pearson correlation between FEP: $\mathrm{Hb} \mu \mathrm{g} / \mathrm{g}$ and Hb levels (Table 2; Fig. 1) as compared to that of parasite density and hemoglobin levels (Fig. 2) were observed. This seem to concur with the argument that the etiology of severe anemia is multifactorial and therefore, there is need to study each of these contributing factors.

It can therefore be speculated that progression to severe anemia during malaria infection and Lead toxicity involves destruction of erythrocytes, inhibition of heme synthesis inhibition (ineffective erythropoiesis) and interference of hepcidin iron regulatory system. The increased erythrocytic clearance due to extrinsic and intrinsic challenges increase the susceptibility to phagocytosis and hence anemia. Reduced serum iron (substrate) availability further complicates the heme

Table 2 Correlation coefficients $r$ and $p$-values of different interacting variables

\begin{tabular}{lll}
\hline Interacting variables & Correlation values $\mathbf{r}$ & $\boldsymbol{p}$-values \\
\hline Parasite density and $\mathrm{Hb}$ & -0.231 & 0.035 \\
$\mathrm{Hb}$ and $\mathrm{BLL}$ & 0.552 & $<0.001$ \\
$\mathrm{Hb}$ and $\mathrm{FEP} / \mathrm{Hb}$ & -0.572 & $<0.001$ \\
$\mathrm{BLL}$ and Parasite density & 0.124 & 0.082 \\
$\mathrm{FEP} / \mathrm{Hb}$, Parasite density $\mathrm{Hb}$ & 0.377 & $<0.001$ \\
\hline
\end{tabular}




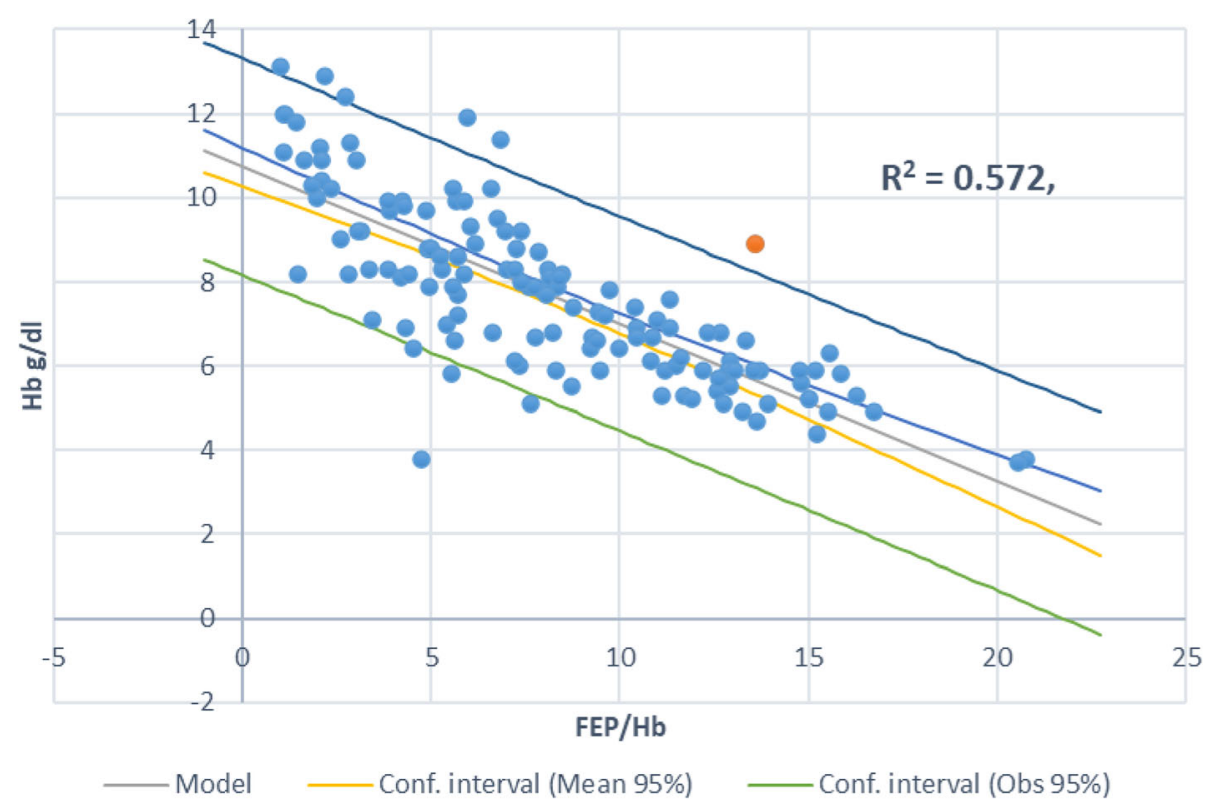

Fig. 1 Scatter graph showing how FEP/Hb levels relate with hemoglobin levels of malaria infected children

synthesis mechanism by disturbing the enzyme /substrate enzymatic reaction equation.

However, this study did not find a direct relationship between high blood Lead concentrations with parasite density as previously reported. It is likely that as BLL increases, hepcidin expression is upregulated decreasing the available serum iron important for parasite survival. Blood Lead levels and malaria parasites (Table 2; Fig. 3) in the study population seems to support the argument that BLL had little or no direct effect on parasite density levels.

Children who participated in the study had no comorbid diseases like HIV, sickle cell traits which are known confounding factors of anemia pathogenesis. This study therefore represents the first reported significant association between malaria and Lead poisoning during the anemia pathogenesis among the pediatric population in Uganda.

\section{Study limitations}

This study did not assess the nutritional status of the participants which is an important confounding factor. We therefore recommend that future studies incorporate nutritional status of participants for a better understanding of the relationship between blood Lead levels and anemia during malaria infection.

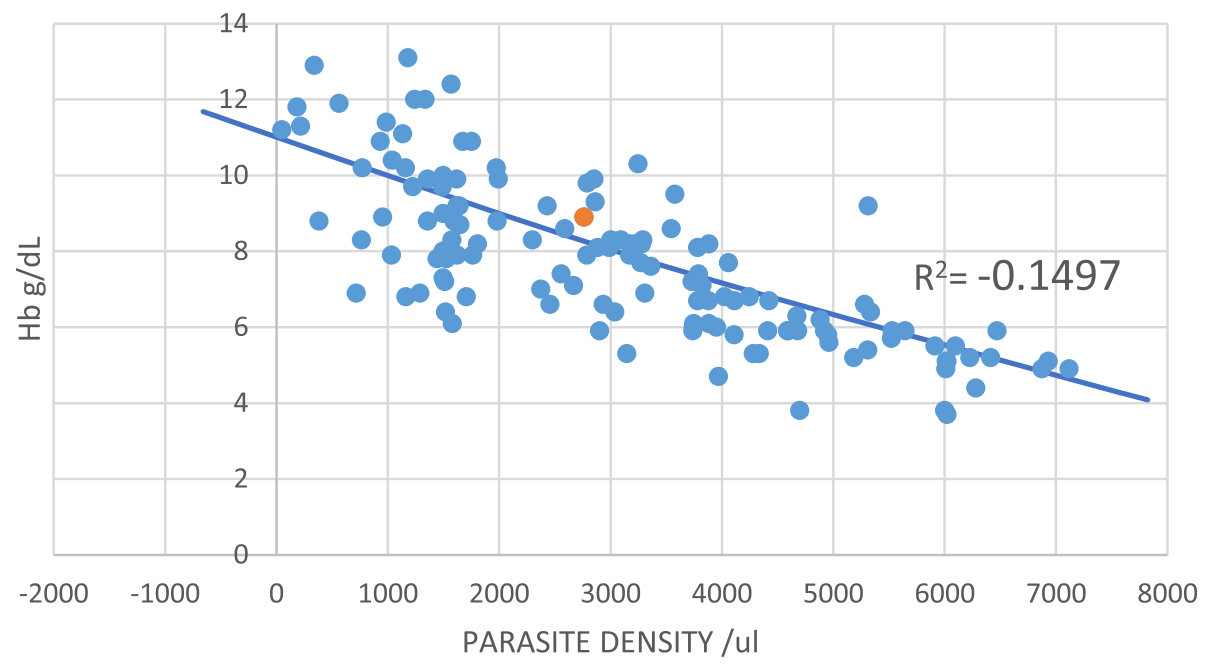

Fig. 2 Scatter graph showing relationship between parasite density and hemoglobin levels among malaria infected children 


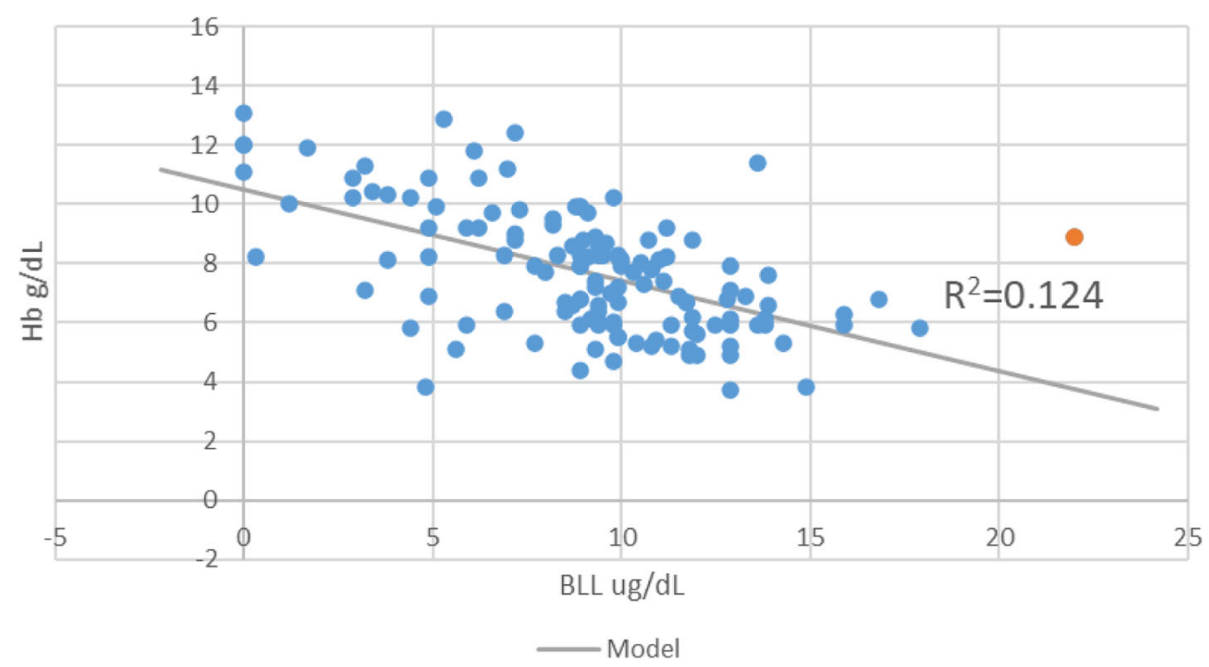

Fig. 3 Scatter graph showing relationship between Blood Lead levels and hemoglobin levels among malaria infected children

\section{Conclusions}

Based on this study findings, low blood Lead is a key confounding factor of anemia pathogenesis especially in children infected with malaria. Since both blood Lead and plasmodium infection geographically overlap with similar hematological consequences, their co-existence heightens the anemia status of the host.

We recommend a detailed study involving a bigger sample size to properly understand the effects and anemia pathogenesis during Lead exposure and Plasmodium malaria infection over a long period of time.

\section{Abbreviations}

ALA: Aminolevulinic acid.; ALAD: Aminolevulinic acid dehydrogenase.; BL: Blood Lead.; BLL: Blood Lead levels.; FEP: Free erythrocyte protoporphyrin.; PD: Parasite density.; PPN: Protoporphyrin.; ZPP: Zinc protoporphyrin.

\section{Acknowledgements}

Acknowledgement goes to all those that participated in this study, most especially the children and parents/guardians of Katanga, Kampala, Uganda. Special thanks go to Mr. Paul Ojambo and Mr. Geofrey Mugenyi of the Department of biochemistry, Makerere University for their invaluable laboratory technical support to this study.

\section{Authors' contributions}

AM conceived the study idea, participated in data acquisition and manuscript preparation; DK participated in data analysis and manuscript preparation; CA participated in data acquisition and analysis; PCV participated in study design and data acquisition; JK participated in the study design, data interpretation, manuscript revision and submission. All authors have read and approved the manuscript for publication.

\section{Funding}

Not applicable.

\section{Availability of data and materials}

The datasets used and/or analyzed during the current study are available from the corresponding author on reasonable request.

\section{Ethics approval and consent to participate}

This study was approved by Gulu University Research Ethics Committee No. (GUREC-048). Parents/guardians were duly explained in a local language, the purpose and benefit of the study to their community and signed consent forms on behalf of their children.

\section{Consent for publication}

Not Applicable.

\section{Competing interests}

No competing interests in this study.

Received: 3 August 2020 Accepted: 31 October 2020

Published online: 14 November 2020

\section{References}

1. SLUMS IN UGANDA. The case of Katanga Slum in Kawempe division, Kampala district Uganda. https://www.academia.edu/...SLUMS_IN_ UGANDA The case of Katanga_Slum .

2. Worrall E, Basu S, Hanson K. Is malaria a disease of poverty? A review of the literature. Tropical Med Int Health. 2005:10(10):1047-59.

3. Mghweno LR, Makokha AO, Magoha HS, Wekesa JM, Nakajugo A. Environmental lead pollution and food safety around Kampala City in Uganda. J Applied Biosci. 2008;12:642-9.

4. Idro R, Aloyo J, Mayende L, Bitarakwate E, John CC, Kivumbi GW. Severe malaria in children in areas with low, moderate and high transmission intensity in Uganda. Tropical Med Int Health. 2006;11(1):115-24.

5. Kamau A, Mtanje G, Mataza C, Mwambingu G, Mturi N, Mohammed S, Snow RW. Malaria infection, disease and mortality among children and adults on the coast of Kenya. Malar J. 2020;19(1):1-12.

6. Yeka A, Gasasira A, Mpimbaza A, Achan J, Nankabirwa J, Nsobya S, Staedke SG, Donnelly MJ, Wabwire-Mangen F, Talisuna A, Dorsey G, Kamya MR, Rosenthal PJ. Malaria in Uganda: challenges to control on the long road to elimination: I. Epidemiology and current control efforts. Acta Trop. 2012 121(3):184-95. https://doi.org/10.1016/j.actatropica.2011.03.004.

7. Mpimbaza A, Ndeezi G, Katahoire A, Rosenthal PJ, Karamagi C. Demographic, Socioeconomic, and Geographic Factors Leading to Severe Malaria and Delayed Care Seeking in Ugandan Children: A Case-Control Study. Am J Tropical Med Hygiene. 2017;97(5):1513-23. https://doi.org/10. 4269/ajtmh.17-0056.

8. Green HK, Sousa-Figueiredo JC, Basanez MG, Betson M, Kabatereine NB, Fenwick A, Stothard JR. Anaemia in Ugandan preschool-aged children: the relative contribution of intestinal parasites and malaria. Parasitology. 2011; 138(12):1534-45

9. Yeka A, Nankabirwa J, Mpimbaza A, Kigozi R, Arinaitwe E, Drakeley C, Staedke SG. Factors associated with malaria parasitemia, anemia and serological responses in a spectrum of epidemiological settings in Uganda. PLoS One. 2015;10(3):e0118901. . 
10. La-Llave-León O, Méndez-Hernández EM, Castellanos-Juárez FX, EsquivelRodríguez E, Vázquez-Alaniz F, Sandoval-Carrillo A, Salas-Pacheco JM. Association between blood lead levels and delta-aminolevulinic acid dehydratase in pregnant women. Int J Environ Res Public Health. 2017;14(4): 432.

11. Bergdahl IA, Grubb A, Schütz A, Desnick RJ, Wetmur JG, Sassa S, Skerfving S. Lead binding to $\delta$-aminolevulinic acid dehydratase (ALAD) in human erythrocytes. Pharmacol Toxicol. 1997;81(4):153-8. .

12. Schwartz J, Landrigan PJ, Baker Jr EL, Orenstein WA, Von Lindern $\mathbb{H}_{\text {. Lead- }}$ induced anemia: dose-response relationships and evidence for a threshold. Am J Public Health. 1990;80(2):165-8.

13. Apostoli P, Romeo L, De Matteis MC, Menegazzi M, Faggionato G, Vettore L. Effects of lead on red blood cell membrane proteins. Int Arch Occup Environ Health. 1988;61(1-2):71-5.

14. Oskarsson A, Fowler BA. Effects of lead on the heme biosynthetic pathway in rat kidney. Exp Mol Pathol. 1985;43(3):409-17.

15. Sassa S. Toxic effects of lead, with particular reference to porphyrin and heme metabolism. In: Heme and hemoproteins. Berlin: Springer; 1978. pp. 333-71.

16. Marsh WL Jr, Nelson DP, Koenig HM. Free erythrocyte protoporphyrin (FEP) I. Normal values for adults and evaluation of the hematofluorometer. Am J Clin Pathol. 1983;79(6):655-60.

17. Osterbauer B, Kapisi J, Bigira V, Mwangwa F, Kinara S, Kamya MR, Dorsey G. Factors associated with malaria parasitaemia, malnutrition, and anaemia among HIV-exposed and unexposed Ugandan infants: a cross-sectional survey. Malar J. 2012;11(1):1-6.

18. Rahman MS, Mushfiquee M, Masud MS, Howlader T. Association between malnutrition and anemia in under-five children and women of reproductive age: Evidence from Bangladesh Demographic and Health Survey 2011. PLoS ONE. 2019;14(7):e0219170. https://doi.org/10.1371/journal.pone.0219170.

19. Wasserman G, Graziano JH, Factor-Litvak P, Popovac D, Morina N, Musabegovic A, Hadzialjevic S. Independent effects of Lead exposure and iron deficiency anemia on developmental outcome at age 2 years. J Pediatr. 1992;121(5):695-703.

20. Wang L, Johnson EE, Shi HN, Walker WA, Wessling-Resnick M, Cherayil BJ. Attenuated inflammatory responses in hemochromatosis reveal a role for iron in the regulation of macrophage cytokine translation. J Immunol. 2008; 181(4):2723-31.

21. Mahaffey KR, Annest JL. Association of erythrocyte protoporphyrin with blood Lead level and iron status in the Second National Health and Nutrition Examination Survey, 1976-1980. Environ Res. 1986;41(1):327-38.

22. Verschoor M, Herber R, Zielhuis R, Wibowo A. Zinc protoporphyrin as an indicator of lead exposure: precision of zinc protoporphyrin measurements. Int Arch Occup Environ Health. 1987;59(6):613-21.

23. Ghosh K, Ghosh K. Pathogenesis of anemia in malaria: a concise review. Parasitol Res. 2007;101(6):1463-9.

24. Oppenheimer SJ. Iron and infection: the clinical evidence. Acta Paediatr. 1989;78:53-62.

25. Levander OA. Lead toxicity and nutritional deficiencies. Environ Health Perspectives. 1979;29:115-25. .

26. Flora G, Gupta D, Tiwari A. Toxicity of Lead: a review with recent updates. Interdisciplinary Toxicol. 2012;5(2):47-58. .

27. Trape JF. Rapid evaluation of malaria parasite density and standardization of thick smear examination for epidemiological investigations. Trans R Soc Trop Med Hyg. 1985;79(2):181-

28. Navarro JA, Granadillo VA, Parra OE, Romero RA. Determination of lead in whole blood by graphite furnace atomic absorption spectrometry with matrix modification. J Anal At Spectrom. 1989;4(5):401-6.

29. Piomelli S. A micro method for free erythrocyte porphyrins: the FEP test. J Lab Clin Med. 1973:81(6):932-40.

30. Balasubramaniam P, Malathi A. Comparative study of hemoglobin estimated by Drabkin's and Sahli's methods. J Postgraduate Med. 1992;38(1):8. .

31. Wright RO, Tsaih SW, Schwartz J, Wright RJ, Hu H. Association between iron deficiency and blood lead level in a longitudinal analysis of children followed in an urban primary care clinic. J Pediatr. 2003;142(1):9-14.

32. Cherian S, Forbes DA, Cook AG, Sanfilippo FM, Kemna EH, Swinkels DW Burgner DP. An insight into the relationships between hepcidin, anemia, infections and inflammatory cytokines in pediatric refugees: a crosssectional study. PloS one. 2008;3(12):e4030.

33. Prakash D, Fesel C, Jain R, Cazenave PA, Mishra GC, Pied S. Clusters of cytokines determine malaria severity in Plasmodium falciparum-infected patients from endemic areas of Central India. J Infectious Dis. 2006;194(2): 198-207.

34. Liu M, Dickinson-Copeland C, Hassana S, Stiles JK. Plasmodium-infected erythrocytes (pRBC) induce endothelial cell apoptosis via a heme-mediated signaling pathway. Drug Des Devel Ther. 2016;10:1009.

35. Cusick SE, Jaramillo EG, Moody EC, Ssemata AS, Bitwayi D, Lund TC, Mupere E. Assessment of blood levels of heavy metals including Lead and manganese in healthy children living in the Katanga settlement of Kampala, Uganda. BMC Public Health. 2018;18(1):717.

36. Nabulo G, Oryem-Origa H, Diamond M. Assessment of lead, cadmium, and zinc contamination of roadside soils, surface films, and vegetables in Kampala City. Uganda Environ Res. 2006;101(1):42-52.

37. Graber LK, Asher D, Anandaraja N, Bopp RF, Merrill K, Cullen MR, Trasande L. Childhood lead exposure after the phaseout of Leaded gasoline: an ecological study of school-age children in Kampala. Uganda Environ Health Perspectives. 2010;118(6):884-9.

38. Shaik AP, Jamil K. A study on the ALAD gene polymorphisms associated with lead exposure. Toxicol Ind Health. 2008;24(7):501-6.

39. da Cunha Martins Jr, A., Mazzaron Barcelos, G. R., Jacob Ferreira, A. L. B., de Souza, M. F., de Syllos Cólus, I. M., Greggi Antunes, L. M., ... Barbosa Jr, F. Effects of lead exposure and genetic polymorphisms on ALAD and GPx activities in Brazilian battery workers. J Toxicol Environmental Health Part A. 2015;78(16):1073-81. .

\section{Publisher's Note}

Springer Nature remains neutral with regard to jurisdictional claims in published maps and institutional affiliations.
Ready to submit your research? Choose BMC and benefit from:

- fast, convenient online submission

- thorough peer review by experienced researchers in your field

- rapid publication on acceptance

- support for research data, including large and complex data types

- gold Open Access which fosters wider collaboration and increased citations

- maximum visibility for your research: over $100 \mathrm{M}$ website views per year

At BMC, research is always in progress.

Learn more biomedcentral.com/submissions 